\title{
A Short History of Anti-Americanism and Terrorism: The Turkish Case
}

\author{
Nur Bilge Criss
}

Throughout the past century, anti-Americanism crescendoed and then subsided in rough proportion to the global power projected by the United States. In Turkey, antiAmerican protests reached a new level of intensity in the late 1960s when U.S. actions challenged Turkey's sovereignty. While subtle acts of resistance came from the military and other government officials, most protests came from ideologically motivated leftists who clashed with equally dogmatic ultranationalists and Islamists. The ensuing battles resulted in the most prolonged era of terrorist violence in modern Turkish history. Thus, anti-Americanism in Turkey can serve as an instructive case study. In this essay I conclude that anti-Americanism stemmed from Turkish efforts to preserve sovereignty as well as from the ideological commitments of the Turkish Left.

Terrorism, the political use of violence to provoke fear, was a different matter. It was reactionary and ethnocentric, concerned with internal conflicts and policies as well as transnational ones. In view of its deep roots and its lethality, some observers suggest that terrorism's causes are irrelevant: Political violence need only be dealt with through punitive legal action. In contrast, in this essay I argue that U.S.-Turkish relations formed part of the context in which terrorism arose and that the history of those relations thus provides cautionary lessons on the sources of anti-Americanism and the terrorism with which it is sometimes associated.

Anti-Westernism in Turkey has differed from that elsewhere in the Middle East. The Turkish republic, as an heir to the Ottoman Empire, has a long tradition of statehood. Although it fought repeated wars against European imperialism from 1911 to 1922, its heartland was never colonized. While Mustafa Kemal Atatürk, the founder of the Turkish republic, was in power (1919-1938), he insisted on independence and sovereignty, but he did not hesitate to seek the "assistance of the Western powers for the peaceful development of Turkey. . . . Modern Turks present an unusual phenomenon - an oriental nation looking to the occident for help in the regeneration of their country." ${ }^{1}$ For once, an "oriental" country had the freedom to

Nur Bilge Criss is assistant professor in the Department of International Relations of Bilkent University, Ankara, Turkey.

Readers may contact Criss at <muge@bilkent.edu.tr $>$.

${ }^{1}$ Gerard Tongas, Atatürk and the True Nature of Modern Turkey, trans. F. F. Rynd (London, 1939), 8. 
do so, guided by its age-old foreign policy orientation toward the West. Extremely jealous of its sovereignty, the young republic was careful in not allowing ties to any foreign power to monopolize its foreign policy until the 1950s. Then dependence on the North Atlantic Treaty Organization (NATO) in general and the United States in particular began to cause repercussions within Turkish society.

\section{Sovereignty and Anti-Americanism}

When Turkey became a member of NATO in 1952, the end of its military and diplomatic isolation brought new issues of sovereignty to the fore. Turkey regarded NATO as an extension of the United States and put few restraints on American action: "the American way was to be exalted as the model . . . little need was felt to insert stringent qualifications on the scope of U.S. activity in Turkey."2 In turn, the Americans used their freedom of action in Turkey for purposes other than simply containing Communism, such as gathering intelligence from within the Soviet Union.

Throughout the 1960s, friction between the Turkish and American militaries increased. In 1960, when the Soviets forcibly grounded a U-2 aircraft that had taken off from Incirlik Air Force Base, a major diplomatic scandal ensued, involving Turkish compliance in violating Soviet airspace. The Turkish press reported the matter as if Turkey had not been involved, and the Turkish government agreed. On May 8, 1960, the Turkish Foreign Ministry announced that the government had never given permission for a U.S. airplane to make reconnaissance flights from its soil and that Turkey bore no responsibility for flights outside its airspace, other than those by its own aircraft. The implication was that the Turkish government had no knowledge of such reconnaissance flights, though the top echelons of the Turkish general staff probably knew. But on May 13, 1960, the Soviets delivered a diplomatic note to Turkey protesting the use of Turkish territory by a third party for intelligence gathering in the Soviet Union. ${ }^{3}$

The issue of sovereignty arose again in 1965 when an American RB-57 reconnaissance aircraft crashed into the Black Sea. Soviet naval authorities informed Turkey of the crash, but the U.S. military mission insisted on investigating the accident unilaterally. The Turkish intelligence and navy claimed that such an investigation was Turkey's affair. The Americans then tried to force their way to the Black Sea through the Dardanelles. A U.S. destroyer did not acknowledge Turkish warnings and made its way from the Aegean Sea to Ahirkapi, Istanbul, but was stopped there by Turkish naval ships. The Turkish navy recovered the black box of the aircraft, and Turkish military intelligence eventually concluded that the American pilot, while flying in a westerly direction over the Soviet border, had exceeded the safe altitude level, and that the airplane had collapsed. ${ }^{4}$

\footnotetext{
${ }^{2}$ George S. Harris, Troubled Alliance: Turkish-American Problems in Historical Perspective, 1945-1971 (Washington, 1972), 45.

${ }^{3}$ Nur Bilge Criss, "U.S. Forces in Turkey," in U.S. Military Forces in Europe: The Early Years, 1945-1970, ed. Simon W. Duke and Wolfgang Krieger (Boulder, 1993), 331-50.

${ }^{4}$ Ibid.
} 
Later that year the government of Prime Minister Süleyman Demirel banned reconnaissance flights from Turkish territory. But the ban did not prevent another incident in 1967. Maj. Gen. Benjamin "Pony" Evans, chief of the Joint United States Military Mission for Aid to Turkey, his American pilot, and his Turkish interpreter were grounded by the Soviets when their airplane entered Soviet airspace while flying over Turkey's eastern border. The American general claimed that they had been on a cultural reconnaissance trip to observe ancient Armenian ruins. Both the Soviets and the Turks eventually accepted this account, but the general's tenure in Turkey was short-lived. ${ }^{5}$

As a result of these incidents, Turkey began to exercise more control over U.S. installations on Turkish territory. Twice Turkey had occasion to remind the United States that bases on Turkish territory could not be used as military staging areas for activities outside the NATO area as defined in Article 6 of the organization's treaty without the permission of the Turkish government. The first occasion was the 1967 Six-Day War between the Arabs and Israelis, and the other was the Lebanon crisis of 1969. At the time of the Six-Day War, "Prime Minister Süleyman Demirel felt it necessary to announce that interference in the 'internal affairs' of another country was not one of the purposes of the joint U.S.-Turkey bases."

Despite the growing sensitivity to issues of sovereignty, the Turkish government continued to court U.S. involvement. In 1959 Turkey had signed a bilateral agreement with the United States whereby it agreed to deploy intermediate range ballistic missiles, Jupiter (SM-78) missiles that could carry nuclear warheads, on Turkish territory under the Agreement Relating to the Introduction of Modern Weapons into NATO Defense Forces in Turkey. That decision brought Turkey dangerously close to nuclear war. During the Cuban missile crisis of 1962, Turkey became the subject of secret diplomacy and of bargaining between President John F. Kennedy and Soviet premier Nikita Khrushchev. In return for the U.S. promise to remove the Jupiter missiles from Turkey, the Soviets would withdraw their missiles from Cuba. Within ten years of joining NATO, then, Turkish decision makers had inadvertently made their country into a bargaining chip in other powers' negotiations, a position dreaded since the nineteenth century. ${ }^{7}$ There was no compelling reason for Turkey to want strategic nuclear missiles on its territory; the risks definitely outweighed the benefits. But Turkish decision makers apparently hoped to increase U.S. strategic dependence on Turkey. Increased aid from the United States might follow at a time when poor harvests and a Europe reluctant to underwrite Turkish public industrial investment programs threatened the ruling Democratic party. Promoting mutual dependence also seemed a way to insure against a possible East-West rapprochement.

\footnotetext{
${ }_{6}^{5}$ Ibid.

6 "The North Atlantic Treaty" <http://www.nato.int/docu/basictxt/treaty.htm> (April 25, 2002); David J. Potter and Gregory J. Stachelczyk, "The Military Relationship between the United States and Turkey since 1947" (M.A. thesis, Air Force Institute of Technology, 1981), 21.

${ }^{7}$ Michael Beschloss, The Crisis Years: Kennedy and Khrushchev, 1960-1963 (New York, 1991); Nur Bilge Criss, "Strategic Nuclear Missiles in Turkey: The Jupiter Affair, 1959-1963," Journal of Strategic Studies, 20 (Sept. 1997), 97-122; Philip Nash, The Other Missiles of October: Eisenhower, Kennedy, and the Jupiters, 1957-1963 (Chapel Hill, 1997).
} 
Before and after the 1960 military coup, Turkish governments justified the placement of the Jupiters as a NATO issue and distinguished the agreement from bilateral relations between Turkey and the United States. That face-saving discourse, however, did not alter the risk associated with such dangerous liaisons during the Cold War. By 1964 the Soviet embassy in Ankara had leaked information about the U.S.-Soviet bargain. Although the Turkish and American governments denied it, leftists in Turkey believed it wholeheartedly. By the time scholars could verify such a bargain (twenty-five years later), the issue had made its way into a Hollywood movie, Thirteen Days. ${ }^{8}$ The crisis was over, but the "rumor" of a bargain contributed to the polarization of the Turkish Right and Left over the American presence.

Turkey's relations with the United States continued to deteriorate. During the 1963 Christmas season, Greek Cypriot militants massacred Turkish Cypriots in attempts to scare their compatriots into emigrating from the island. The Turkish government tried to orchestrate pressure by Turkey, Great Britain, and Greece in their legal role as guarantor states of the republic of Cyprus. To put pressure on the parties and as a last resort, Prime Minister Ismet Inönü suggested that Turkey might intervene unilaterally, after which President Lyndon B. Johnson sent him a letter. The Johnson letter cautioned Inönü: If unilateral Turkish action on the island invited a Soviet attack, then NATO was not obligated to defend Turkey. The letter was leaked to the Turkish press. Clearly intended for domestic consumption, it served to put the blame for Turkish inaction in Cyprus elsewhere. Turkey had few means to carry out such action as the Turkish military had no landing vessels. The letter saved Turkey from a probable failure in an action that Inönü had not wanted to engage in. ${ }^{9}$ However, its wording brought home the fact that the national security interests of Turkey and of its allies were not necessarily confluent. The Johnson letter was a turning point in the Turkish shift toward a multidimensional foreign policy.

Meanwhile, a social problem in the United States that was totally unrelated to defense issues, increased drug addiction and drug-related crime, gave rise to a political problem between the allies. American diplomats were not able to convince the elected governments, as of 1965 , that Turkey should ban cultivation of the opium poppy in the west-central Anatolian plains. Ninety thousand Anatolian families were engaged in opium farming. The Turkish government, which feared both losing votes and appearing unconditionally pro-American, did not respond to American requests. By 1971 reports to the U.S. House and Senate indicated that 80 percent of the illicit drugs in the U.S. were smuggled from Turkey. The U.S. government hoped to stop the problem at the source. After the 1971 Turkish coup, Prime Minister Nihat Erim of the new nonpartisan technocratic government agreed to ban opium cultivation "for humanitarian reasons." The farmers were financially compensated, but they saw the change as economic suicide. In 1974, when Bülent Ecevit was elected prime minister, he decreed that the cultivation of poppies for opium would be permitted in seven provinces. The United States threatened to cut off aid to Turkey, and editorials

\footnotetext{
${ }^{8}$ Thirteen Days, dir. Roger Donaldson (New Line, 2000).

9 George S. Harris argued that Lyndon B. Johnson's letter was convenient for the Turkish government at the Conference on Turkish Foreign Policy, Bilkent University, Ankara, spring 1999.
} 
in the U.S. press suggested bombing the poppy fields in Turkey. By then drug traffic from the Golden Triangle region (in Southeast Asia) to the United States outweighed the illicit trade from Turkey, but the latter seemed a closer and an easier target. Turkey cooperated with the United Nations (UN) and the U.S. Drug Enforcement Administration to develop a control plan that limited cultivation areas. The poppy straw harvesting technique, which eliminated production of the opium gum used in manufacturing heroin, proved effective. Soon after, opium became a nonissue in Turkish-American relations. But for the political Left in Turkey and for many ordinary citizens, this was just another example of harsh U.S. treatment of Turkey as a client state, not an ally. ${ }^{10}$

In 1974 another Cyprus crisis further deteriorated pro-American sentiments. After a coup on the island, the new leader, Nikos Sampson, whom an American scholar has described as an "international terrorist," hoped to rid the island of Turkish Cypriots and to annex Cyprus to Greece. Turkey, Great Britain, and Greece were by treaty the guarantors of the republic of Cyprus. Greece, then ruled by a military junta, supported Sampson. After exhaustive diplomatic efforts to mount a two-power BritishTurkish intervention failed, Turkey undertook military operations. In 1975 the U.S. Congress placed an embargo on transferring military equipment to Turkey on the premise that U.S. military equipment was not to be used for non-NATO purposes. Ankara retaliated by suspending all U.S. base operations on Turkish territory. The bases and a reduced number of American personnel remained, but their activities were curtailed. The embargo was lifted in 1978, but the disputes had fed the political Left's anti-American "anti-imperialism." Anti-Americanism, coupled with the mismanagement of dissent by successive Turkish governments, resulted in prolonged domestic terrorism until the 1980 military coup. ${ }^{11}$

\section{Ideologically Motivated Anti-Americanism}

In the 1960s the Turkish political system was dominated by two parties: the secularist Republican People's party (RPP), created by Atatürk at the founding of the republic, and the Justice party (JP), a probusiness and anticommunist party dating from the 1950s. The military generally left politics to elected civilians, although there had been a coup in 1960 (to be followed by coups in 1971 and 1980). From 1961 to 1965, Turkey was ruled by coalition governments headed by the RPp leader, Ismet Inönü. In the 1965 and 1969 general elections, the JP won the majority of the popular vote.

${ }^{10}$ Harris, Troubled Alliance, 191-98; James W. Spain, “The United States, Turkey, and the Poppy," Middle East Journal, 29 (Summer 1975), 295-309.

${ }^{11}$ Bruce Kuniholm, "Turkey and NaTO: Past, Present, and Future," Orbis, 27 (Summer 1983), 421-45; Süha Bölükbasi, "The Cyprus Dispute and the United Nations: Peaceful Non-Settlement between 1954 and 1996," International Journal of Middle East Studies, 30 (Aug. 1998), 411-34; U. Haluk Bayülken, "The Cyprus Question and the United States," Foreign Policy (Ankara), 4 (nos. 2-3, 1974); Richard Company, Turkey and the United States: The Arms Embargo Period (New York, 1986); Arthur Chester, "Controversy over the Cut-off of Military Aid to Turkey," Congressional Digest, 54 (April 1975), 99-128; Paul Y. Watanabe, Ethnic Groups, Congress, and American Foreign Policy: The Politics of the Turkish Arms Embargo (Westport, 1984); Albert Wohlstetter, "The Strategic Importance of Turkey and the Arms Embargo," Journal of International Relations, 3 (Summer 1978), 101-9. 
In Turkey as elsewhere, the 1960s saw an upsurge in political interest and activity among liberal intellectuals and leftists, including many university students. They called for social justice, land reform, a more equitable distribution of income, and nonalignment, and anti-American and anti-Vietnam War sentiments helped fuel their radicalism. Leftist intellectuals had established the Turkish Labor party (TLP) in 1961, but it never garnered more than 3 percent of the popular vote. The party program advocated socialism through parliamentary democracy. The mere existence of the party, however, aroused the latent fear of Communism. In 1963 a member of the right-of-center JP founded the Turkish Association to Combat Communism. ${ }^{12}$

When in 1963 the leader of TLP made public the contents of secret bilateral agreements between Turkey and the United States, the government was obliged to renegotiate them because some clauses were incompatible with Turkish sovereignty. But radicals demanded that Turkey withdraw from NATO altogether. The NATO issue came to a head on April 19, 1966, when the U.S. secretary of state, Dean Rusk, arrived in Turkey to attend the Central Treaty Organization (CENTO) meetings. The debate club of Ankara University's political science faculty held a protest meeting, denouncing NATO and CENTO as opposed to the principles of Turkish independence. When the leftist Türk-Is trade union organized a protest demonstration on behalf of Turkish workers employed on U.S. bases, students and workers for the first time shouted anti-American slogans on Turkish city streets. ${ }^{13}$

Leftist students viewed the JP government of Süleyman Demirel as supporting the "monopolist bourgeoisie," which collaborated with "U.S. imperialism" and subordinated the Turkish economy to it. When the rightists staged demonstrations in 1966 and 1968 to "condemn Communism," leftists reacted with demonstrations to "condemn the United States," and they were immediately physically attacked by rightist militants. When the U.S. Sixth Fleet visited Istanbul in 1968, university students protested. Some American sailors were thrown into the Bosporus. And during the ensuing riots, one student was killed by Turkish security forces. ${ }^{14}$ This was a defining moment for the Turkish Left and proponents of Third Worldism in Turkey. By 1969 terrorist acts had begun. Leftist militants began sincerely to believe that Turkey was ripe for a socialist revolution. Rightist commandos mobilized to fight them. The government could no longer rely on its undermanned security forces, which were also ideologically divided.

\footnotetext{
12 On the Turkish Labor party, see Hikmet Ozdemir, "Siyasal tarih, 1960-1980" (Political history, 19601980), in Çagdas Türkiye, 1908-1980 (Contemporary Turkey, 1908-1980), ed. Sina Aksin (Istanbul, 1990), 22123. On the Turkish Association to Combat Communism, see Jacob Landau, Türkiyéde sag ve sol (Radicalism in Turkey) (Ankara, 1979), 305-9; and Rafet Balli, "Komünizmle Mücadele Derneklerinden Bugüne Gladyonun MHP operasyonu" (Gladio and the Nationalist Action party from the Association to Combat Communism to today), in Bati ve irtica (The West and fundamentalism), comp. Ferit Ilsever (Istanbul, 1999), 506-12.

${ }^{13}$ On July 3, 1969, a Defense Cooperation Agreement (DCA) was signed between Turkey and the United States to codify previous bilateral accords. Only a few of the accords had been on paper. From 1970 onward, DCAs were renewed periodically. See Richard F. Grimmett, United States Military Installations in Turkey (Washington, 1984). Mehmet Gönlübol and Omer Kürkcüoglu, "1965-1973 dönemi türk dis politikasi” (Turkish foreign policy between 1965 and 1973), in Olaylarla türk dis politikasi, 1919-1995 (External and internal events that shaped Turkish foreign policy, 1919-1995), ed. Mehmet Gönlübol (Ankara, 1996), 491-540.

${ }^{14}$ Bilge Criss, "Mercenaries of Ideology: Turkey's Terrorism War," in Terrorism and Politics, ed. Barry Rubin (New York, 1991), 125-50, esp. 128.
} 


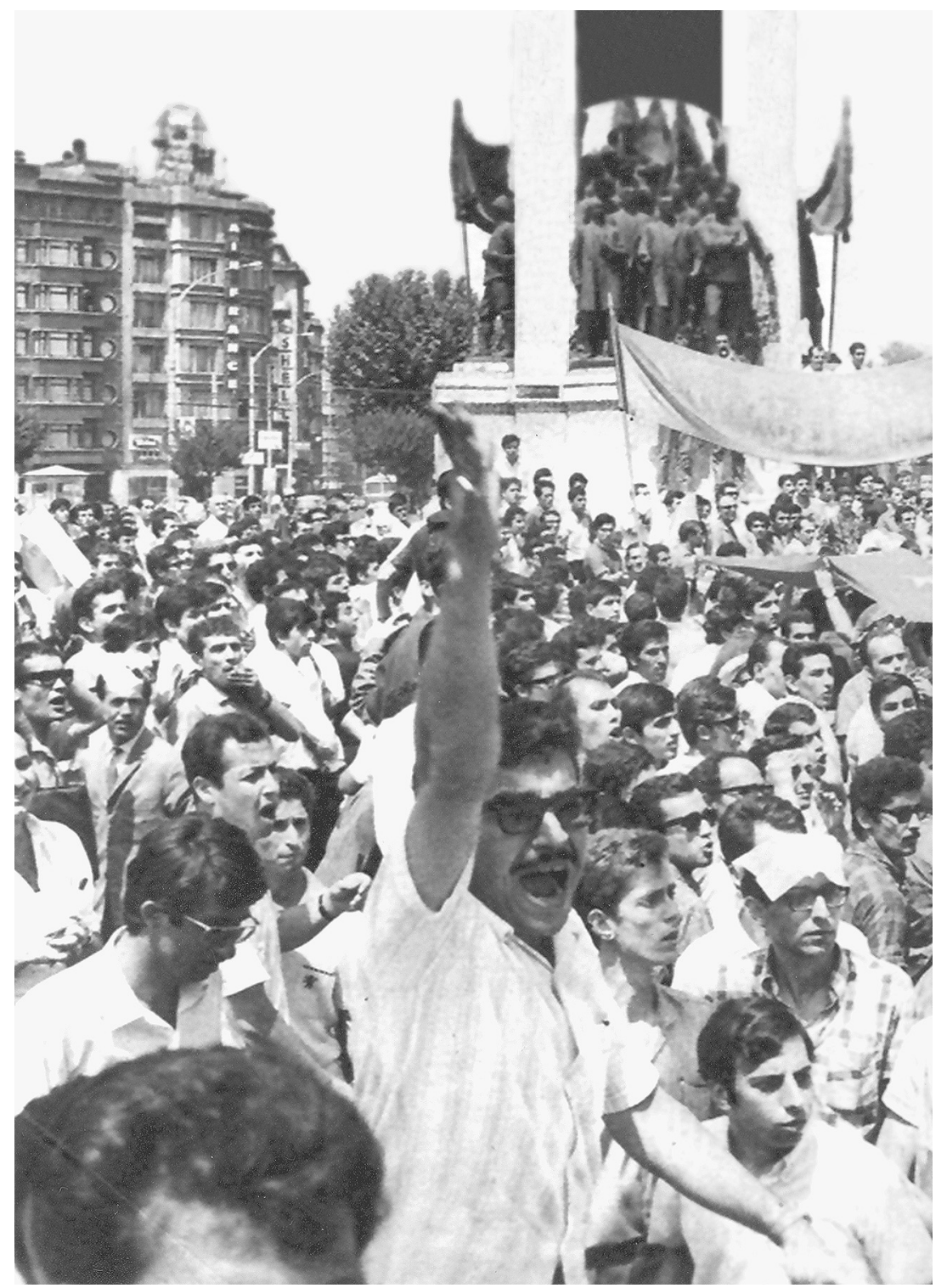

Turks protest against the visit of the U.S. Sixth Fleet in Istanbul, July 1968. Courtesy Fahri Aral, Bilgi University, Istanbul.

The government introduced the religious element into the struggle in an attempt to combat Communism. Both leftists and rightists were militantly active on university campuses. Schools training imams (Muslim religious officials), which before 1965 used to be vocational schools, were elevated to the status of secondary schools and by 1973 were made coeducational, although women cannot hold office as imams 


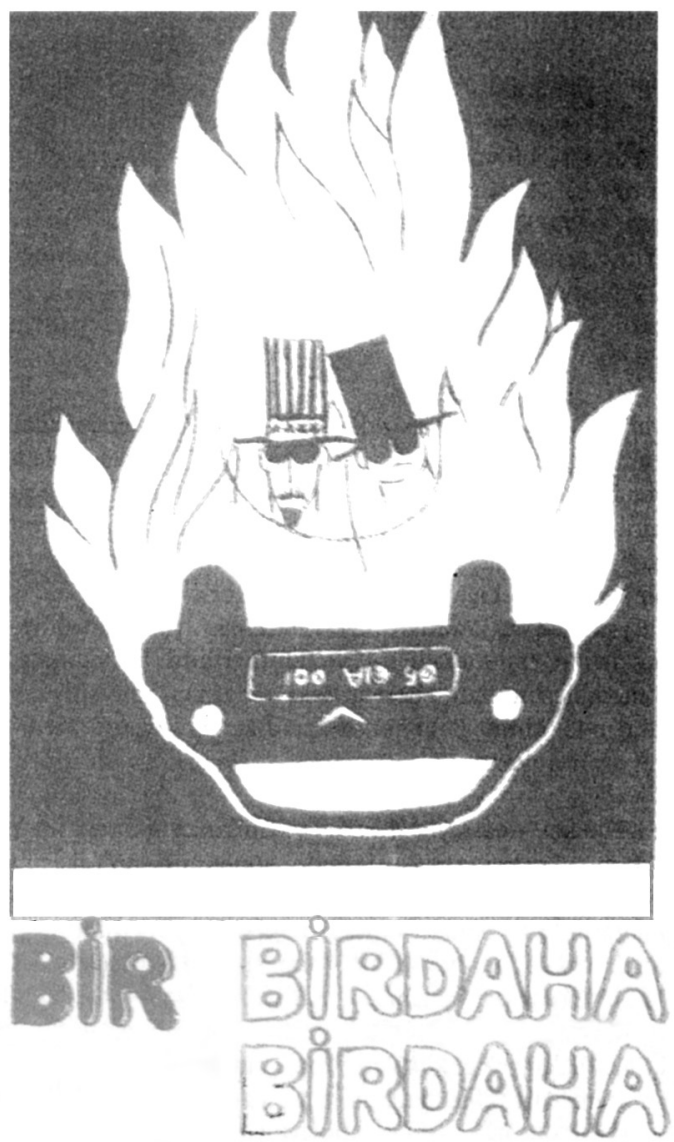

A poster depicts the burning of U.S. ambassador Robert Komer's car at the Middle East Technical University in Ankara, 1969. The figure next to Uncle Sam represents members of the Turkish government whom socialists saw as collaborating with the United States. Bir daha bir daha (once again) calls for a renewed fight for national independence. Courtesy Fahri Aral, Bilgi University, Istanbul.

in the Sunni branch of Islam that prevails in Turkey. An amendment to the National Education Basic Law opened the route for graduates of imam-lycées (high schools) to enter the universities. ${ }^{15}$ The government was obviously trying to neutralize leftist militancy in the universities. The new law both increased attendance at religious lycées and imported religious conservatism into higher education as lycée graduates became more numerous and vocal in the universities.

Not only was Atatürk's principle of a unified, secular education based on the positive sciences thereby undone, but the process added fuel to the fire. On February 16, 1969, leftists held a demonstration, "the Mustafa Kemal march against imperialism." The same day the Bugün newspaper called the Islamic faithful to mass prayer and

${ }^{15}$ Halis Ayhan, Türkiye'de din egitimi, 1920-1998 (Religious education in Turkey, 1920-1998) (Istanbul, 1999), 200-203. 
cautioned them that guns might explode. Explode they did: Fanatic religious militants attacked the leftist demonstrators, killing 2 people and wounding 104. Strikes, boycotts, and demonstrations then paralleled the economic problems. Some opportunistic politicians began to blame the social and economic ills of the country on deviations from traditional religious practice. In 1970 a former engineering professor, Necmettin Erbakan, founded the National Order party, which claimed to represent the interests of Muslims and rejected Turkey's secular, Western orientation. (Between 1970 and 1983, Erbakan established three political parties, all of which were eventually banned by the Constitutional Court, the latest the Welfare party in 2000.$)^{16} \mathrm{~A}$ revival of religious brotherhoods followed, except that the brotherhoods no longer dealt with spiritual issues or mysticism. They were venues for training young minds who became religious reactionaries par excellence. Consequently, there was a readymade pool for "Islamic" militancy and terrorism.

On March 12, 1971, the military issued a communiqué accusing the government of having led the country into anarchy, fratricidal strife, and social and economic unrest. The government resigned, to be replaced by a nonpartisan government of technocrats. The civilian politicians faced opponents who would not compromise. On the one hand, the young militants of the Left would not settle for the left-ofcenter position of the RPP any more than for the parliamentary socialism that TLP represented; they wanted revolution. On the other, the 1971 coup-by-communiqué was intended to settle scores among the military leadership. In the armed forces high command mutual suspicion was rampant, some fearing a socialist coup, others a rightist coup. After the coup the conservative military faction managed to retire the leftist opposition. ${ }^{17}$

Leftist and rightist ideological movements were thus the catalysts for terrorism during the 1970s. Left-wing activists, especially, opted for terrorism when they realized that leftist parties did not receive sufficient votes to make any difference in Turkish politics. Moreover, youth movements worldwide and theoreticians of the New Left—such as Regis Debray, Che Guevara, and Carlos Marighella—left an indelible mark on Turkish radicals.

The leftist militants had international ties. Some trained in the camps of the Palestine Liberation Organization's (PLO) al-Fatah group in Jordan. Others were trained by Kurdish rebels in Iraq. In June 1972 fourteen armed terrorists were caught after they had infiltrated into Turkey on a boat that belonged to al-Fatah and had begun rural and urban guerrilla warfare. Approximately four hundred Turkish militants had gone

\footnotetext{
${ }^{16}$ The Constitutional Court banned the parties Necmettin Erbakan founded because they violated Article 14 of the Turkish Constitution: "None of the rights and freedoms embodied in the Constitution shall be exercised with the aim of violating the indivisible integrity of the state with its territory and nation, of endangering the existence of the Turkish State and Republic, of destroying fundamental rights and freedoms, of placing the government of the state under the control of an individual or a group of people." The Constitution of the Republic of Turkey (Ankara, 1995), 9; or Anayasa Mahkemesi Karari <www.Anayasa.Gov.tr/KARARLAR/SPK/K1998/K199801.htm> (June 6, 2002). The European Court of Human Rights concurred with the Turkish Constitutional Court verdict. See "Affaire Refah Partisi (Parti de la Prospérité) et Autres c. Turquie" (Case of the Refah party [Prosperity party] and others v. Turkey), July 31, 2001, HUDOC <http://hudoc.echr.coe.int/hudoc/> (June 6,

${ }^{17}$ Criss, "Mercenaries of Ideology," 131-33.
} 2002). 


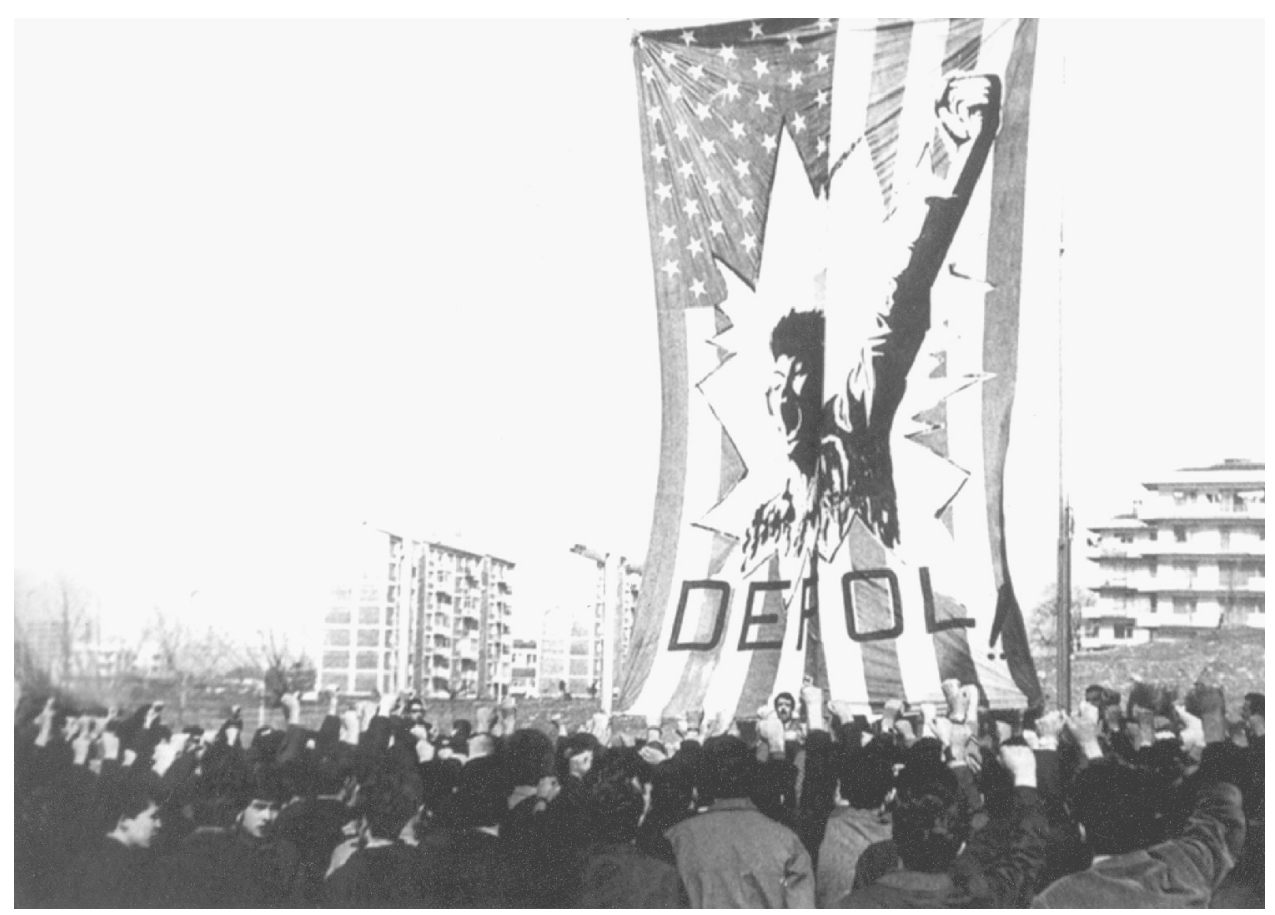

The Revolutionary Youth organization holds an independence demonstration in Istanbul, Turkey, in March 1970. The banner bears the indignant slogan Defol!: Get out! Courtesy Fahri Aral, Bilgi University, Istanbul.

to the Palestinian camps alone. In May 1971 the Turkish People's Liberation Army/ Front (TPLA-F) kidnapped and murdered the Israeli consul general of Istanbul, Ephraim Elrom. The TPLA-F defendants argued that their purpose was to demonstrate solidarity with the Palestinians. But Elrom had been murdered for giving the Turkish security forces the names of Turkish terrorists trained in Palestinian camps. ${ }^{18}$

Right-wing terrorist forces included both secular and religious groups. By 1968 the Nationalist Action party (NAP) had established commando camps to train young men, under military discipline, to combat Communism. The Idealist Youth Associations (the Grey Wolves), the militant organ of the NAP, became bolder in inciting violence. The majority of their recruits were unemployed, unskilled youth from shantytowns. Ten militant religious groups existed. These included the Islamic Liberation Army, the Turkish-Islamic Liberation Union, the Turkish-Islamic Liberation Front, the Suicide Corps of the Shari'a, and the Turkish Revolutionary Shari'a Army. None of these titles pointed to peaceful intentions.

As of 1975 universities, high schools, labor unions, security forces, and political parties were polarized to the point of no return. Radical factions of leftists, ultranationalists, and religious fundamentalists murdered opponents, occupied shantytown neighborhoods and university dormitories, and robbed or extorted money from busi- 
nesses big and small; the last two groups assassinated liberal and socialist intellectuals. This scene marked Turkey's domestic history between 1975 and 1980. In 1977 the minister of the interior alerted the cabinet about increased violence perpetrated by commando hit teams. Süleyman Demirel, once again prime minister, remained adamant. He would not admit that the rightists committed terrorist crimes. He was riding too wild a tiger.

The consequence was the 1980 coup, which led to an unanticipated rapprochement of forces on the right. The 1980 military coup makers did not distinguish between the Right and the Left when it came to punitive action- to the chagrin of the former, whose militants had previously been protected by the government. While in jail many nationalist commandos merged their ideology with militant Islam. Religious literature was abundant in prisons whereas secular literature was limited, encouraging the widespread conversion of the formerly "pagan" Grey Wolves who served time alongside members of the Raiders Association (Akincilar), the youth branch of Erbakan's National Salvation party (NSP). Their ideology centered around an Islamic revolution, and they rejected nationalism and democracy as doctrines alien to Muslims.

One may never know how extensively the Turkish government consulted with the United States on combating terrorism, any more than one can pinpoint with exact precision whose idea it was to combat alleged Soviet influence, infiltration, and subversion by promoting Islam against "atheist Communism." But a radical change was observed in the aftermath of the 1980 military coup in Turkey. The generals began citing verses from the Koran. An amorphous concept of Turkish-Islamic synthesis was introduced into the schools. Compulsory courses on religion promoted Sunni religious identity. And Saudi financial establishments that provided an alternative to banks were suddenly permitted into the country. These establishments were not only tax-exempt; they refused to pay and to charge interest (regarding it as usury) and distributed shares from profits-a practice that had no precedent in republican Turkey. ${ }^{19}$ It took almost a decade of flirtation with Islam before the policy makers realized (after having ignored the historical record) how dangerous a force politicized religion was. In 2000, the so-called Islamic political party, the Welfare party, was banned by the Constitutional Court. By then Turkey was facing terrorism instigated by the Hezbollah, as well as the assassinations of renowned secular intellectuals by other religious reactionaries. Currently, Turkish policy makers are still trying to curb the political Islam and the terrorism, albeit subdued, that were offshoots of their predecessors' efforts to politicize religion.

\section{Issues Today}

The history related here is relevant to at least three major foreign policy issues that should concern the United States. First, the United States needs to overcome its his-

\footnotetext{
${ }^{19}$ On compulsory school courses about religion, see Ayhan, Türkiye'de din egitimi, 207-8. On the Saudi financial establishments, see Enis Berberoglu, "Petro-dolarlar ve islami bankacilik" (Petrodollars and Islamic banking), in Bati ve irtica, comp. Ilsever, 122-29. Bozkurt Güvenç, et al., Türk-islam sentezi (Turkish-Islamic synthesis) (Istanbul, 1991).
} 
tory of violating the sovereignty of other nations. This requires asserting power without pretensions to hegemony. Historically, world systems never took graciously to hegemons, be it under universal empires, a universal church, a seafaring empire over which "the sun never set," parvenus such as Napoleon Bonaparte and Adolf Hitler, or ideologues such as Vladimir Lenin or Joseph Stalin. International coalitions or overextension always curbed the ambitions of those with hegemonic aspirations. By 1993 George F. Kennan, the architect of containment policy, renounced the U.S. role in the Cold War, stating, "I should make it clear that I'm wholly and emphatically rejecting any and all messianic concepts of America's role in the world, rejecting that is, an image of ourselves as teachers and redeemers to the rest of humanity, rejecting the unique and superior virtue on our part, the prattle about Manifest Destiny or the American Century." ${ }^{20}$ It is perhaps the messianic attitude more than anything that Kennan is rejecting, for that, too, feeds anti-Americanism. Projecting an image of omnipotence usually results in higher expectations than even the United States is capable of delivering, and, ironically, it results in others' asking why the mighty power cannot, for example, deliver justice on the Palestinian issue.

Second, the Bush administration should rethink its proposed national missile defense system. The proposal is already domestically controversial. ${ }^{21}$ There are indications that the administration is contemplating sharing this system with allies, that is, placing the system, or parts of it, outside the United States. Some allied leaders may jump on the bandwagon. Turkey, however, has seen the spillover effects of the Cuban missile crisis and will rightly proceed with caution if confronted with such a "defense." At certain times, deterrence can become unduly provocative, not only for regional powers such as Turkey, but for nuclear powers, however latent their animosities are today.

Third, and perhaps most important, the United States and its allies must not rely on religion to counter anti-Americanism or terrorism. Some now believe that governments should back "moderate Islam" as opposed to "radical Islam." During World War II, the Allies lambasted fascist totalitarianism while downplaying their dependence on the Soviet totalitarian state. Perhaps that victory actually made the world safe for Communism, considering how rapidly it spread in the aftermath of the war. ${ }^{22}$ It is just as dangerous to rely on "moderate Islam" and to legitimate religiously oriented power. Politicized religion generally becomes extreme. The moderation (or lack thereof) of politicized religion should not be measured by its pro- or anti-American stance. What may seem pro-Americanism on the surface may breed hostility to the pro-American leadership, and it may focus on the United States for the wrong reasons. There has scarcely been any difference between the efforts to subvert Turkey's secular regime by "anti-American" Iran and by "pro-American" Saudi Arabia, except that the latter is more subtle. As early modern and modern European history attests, many struggles had at their core the confining of matters of faith to the private realm

\footnotetext{
${ }^{20}$ Francis Stonor Saunders, The Cultural Cold War: The CIA and the World of Arts and Letters (New York, 1999), 413-14.

${ }^{21}$ Steven Weinberg, “Can Missile Defense Work?,” New York Review of Books, Feb. 14, 2002, pp. 41-47.

${ }^{22}$ Richard Overy, Why the Allies Won (New York, 1996), 2-24.
} 
and away from the public sphere. Turkey has not remained untouched by such struggles, but it is the only majority-Muslim country to have succeeded in secularizing. While many observers in Turkey see Saudi Arabia as the most radical financial nurturer of political Islam in the country since the 1980s, Western observers, with a few exceptions, have not recognized the dangers of the Saudi version of Islamic influence. $^{23}$

Following the dissolution of the Soviet Union in 1991, the former Soviet republics in Central Asia and the peoples of the Caucasus were often presented in terms of their alleged religious identity, that is, as Muslims. For the East, many scholars and journalists still promote religious and ethnic identities at the expense of national identities, but that is hardly the case for the West. In 1995 Graham E. Fuller and Ian O. Lesser argued that it was the refusal to extend legitimacy to Islamic movements that created polarization and radicalism. Others argue that disappointment with "secular" governments and modernization pushed many Muslims to seek social justice in Islamic movements. Add on the injustices ascribed to the United States, and one supposedly gets to the core cause of recent terrorisms. ${ }^{24}$ But one should note the incredible similarity between the aggressors and the like-minded "moderate" political Islamists in Turkey today. Their view is that the United States is to blame for the attacks of September 11, 2001, and some American analysts, too, look for causes within and fault U.S. policies. But power, dominance, and opposition work in complex ways on the global scale. We need to assess U.S. policies critically, but we should not assume that problematic policies justify either terrorism or catering to politicized religion. The main questions are how the United States will manage the gift and the burden of power and when anti-Americanists of all shades will begin critical selfanalysis, away from concepts such as the "exploiters" and the "exploited," which assume that the latter have always lacked will and agency.

In conclusion, U.S. policies as well as American messianic attitudes have fed the antiAmericanism that also results from ideological commitments. Terrorism far exceeds any anti-American sentiment; it is nihilistic and needs to be dealt with by force and legal punitive action. Yet, we should still examine its history and take whatever steps we can to prevent it in the future.

\footnotetext{
${ }^{23}$ Isabel Vincent, "How Saudis Became Extremism's Exporters," National Post (Toronto), Oct. 26, 2001, in Turkistan Newsletter, Oct. 29, 2001 <http://www.euronet.NL/users/sota/turkistan.htm\#arch> (June 25, 2002); John Hooper and Brian Whitaker, "Extremist View of Islam Unites Terror Suspects: Salafi Purist Teaching Backed by Saudi Royals," Guardian (Manchester), Oct. 26, 2001, ibid., Oct. 29, 2001; Stephen Schwartz, "Saudi Friends, Saudi Foes: Is Our Arab Ally Part of the Problem?," ibid., Nov. 22, 2001; David Wurmser, "The Saudi Connection: Osama Bin Laden's a Lot Closer to the Saudi Royal Family Than You Think,” ibid.

${ }^{24}$ Graham E. Fuller and Ian O. Lesser, A Sense of Siege: The Geopolitics of Islam and the West (Boulder, 1995), 122-66; Richard Falk, "World Order after September 11: An Unmapped Minefield," Turkish Daily News (Ankara), Jan. 5, 2002, p. 16.
} 